\title{
Village Empowerment Opportunities Through Social Forestry
}

\author{
Wartiningsih* \\ Faculty of Law, University of \\ Trunojoyo Madura \\ E-mail: wartiningsih@trunojoyo.ac.id
}

\author{
Nunuk Nuswadani \\ Faculty of Law, University of \\ Trunojoyo Madura \\ E-mail: nooq.fh@gmail.com
}

\author{
Febrian \\ Faculty of Law, University of \\ Sriwijaya \\ E-mail: febrian_zein@yahoo.com
}

\begin{abstract}
This paper is based on the less optimal results achieved by the Social Forestry program. On the other hand, the use of village funds is mostly used for village apparatus spending and physical development that cannot yet provide economic benefits. The government's desire that development start from the village also does not fully show significant results. When in fact the village is very possible to transform themselves into more empowered village. Through village empowerment not only based on the community but also the creation of sustainable and unique village spaces by the community. The problem in this paper is whether there are opportunities to empower villages through the Social Forestry program or not? This research is a normative study, which is moving from the existing issues in the legislation, using descriptive approach, analyzed qualitatively.
\end{abstract}

Keywords: village empowerment, social forestry, village funds

\section{INTRODUCTION}

Forest resources management in several countries including Indonesia before 2000 is still based on the state. After experiencing history and through long scientific discourse, in 2000 Indonesian Forests Understanding (KHI) emerged which ultimately influenced government policies in the field of forest resource management. Various policies have changed their paradigm towards community based forest management. Law Number 41 of 1999 concerning Forestry represents the paradigm of state based forest management in which the state as the one who controls the forest, regulates, grants permits and so on. While Law Number 18 Year 2013 concerning Prevention and Eradication of Forest Destruction and Regulation of the Minister of Environment and Forestry Number: P.83//MENLHK/SETJEN/KUM.1/6/2016 regarding Social Forestry represents community based forest management.

In practice, it turns out that the social forestry program is not running optimally. It turned out to just stop at the giving of social forestry permit, but has not been followed by the program - an advanced program to strengthen the ability of residents around the forest. Many things contributed to the failure of the social forestry program, for example there was no support from stake holders. Based on the description above, a problem can be formulated: is there an opportunity to empower villages through the Social Forestry program?

\section{METHODOLOGY}

This research type is normative research that uses data sources in the form of secondary data in the form of legislation, expert opinions and research results. As dogmatic legal research then the approach used is prescriptive, namely compulsion in the science of law.

\section{RESULT AND DISCUSSION}

\section{A. Profile of Village Government in Indonesia}

In 2018 the Central Statistics Agency recorded that there were 83,931 rural level administrative regions in Indonesia in 2018. The number consisted of 75,436 villages $(74,517$ villages and 919 nagaris in West Sumatra). Law Number 6 of 2016 concerning Villages [1], defining village, is legal community unit with territorial boundaries that are authorized to regulate and manage government affairs, the interests of local communities based on community initiatives, original rights, and/or recognized traditional rights and respected in the government system of the Unitary Republic of Indonesia.

The village under the leadership of a village head runs the village administration. The village government as the unit of government institution closest to the community is expected to be able to run the village administration seriously and be able to change the standard of people living towards a more prosperous, just, peaceful, safe, and peaceful way. The government's determination to make the village as base for the country development, because the village was given the widest opportunity to develop themselves based on the principles of recognition, diversity, diversity, togetherness, mutual cooperation, kinship, deliberation, democracy, democracy, independence, participation, equality, empowerment, and continuity.

\section{B. Social Forestry Program}

Social Forestry as outlined in [2] is deemed to represent the community-based forest management. Because it contains the participatory principle in addition to the principles of justice, legal certainty, sustainability and the principle of accountability.

In studies from China, India and the Philippines, for example, it was revealed that the Forestry Department saw Community Based Forest Management as route for more effective forest land management with the potential to 
achieve higher levels of success in large-scale reforestation programs (Yangtze Shelterbelt Project) during the 1990s in Sichuan and Yunnan provinces in China), or as a strategy to reduce erosion and land degradation in highland areas (the Philippines) [3]*.

Social Forestry has 3 (three) pillars, namely: (1) land; (2) business opportunities and (3) human resources. Through these 3 (three) pillars, development will not only focus on urban areas but will also lead to rural communities or the surrounding forests. Of course the objective of this program is economic equality so that welfare increases and more effective model of forest management is created.

The participatory principle requires that the management of forest resources not only be the responsibility of the Government but also the responsibility of the community. The principle of participation led to the principle of coownership, the principles of management and the principle of responsibility. Those principles actually covers the efforts of empowerment.

\section{Village Empowerment Opportunities through Social Forestry}

\section{a. Regulation of the Minister of Environment and Forestry}

For villages adjacent to the forest area managed by Perum Perhutani, they have the opportunity to develop and prosper their communities through the Cooperation Agreement (PKS) scheme, through the program, there are already many farmer groups incorporated in LMDH obtain it. However, many of them have not yet to be implemented because they have not yet found third party that able to fund the launched program

Based on the study results [4], several LMDHs have entered into agreement with the manager $(\mathrm{KPH})$ but there is no visible impact that can be felt by the community. The reality is that between $\mathrm{LMDH}$ and the Village it works independently, even if there is a will from the Village, it is possible to develop the village through village funds. For this reason, there is a need for synergy between stakeholders, namely LMDH, villages, NGOs and academics.

In Article 63 [2] stipulates that Social Forestry funding can be sourced from village funds. This article clearly that the stakeholders can take advantage of the village fund managing forest resources collaboratively.

It was stated that through Social Forestry the village became empowered due to the stipulation of several principles in Article 3 [2] namely:

1. The principle of justice, the State is not the owner of the earth, water and land but only controls, through social forestry, the state gives permission to the community through 4 (four) management schemes, namely: (1) Village Forest; (2) Community Plantation Forests; (3) Customary Forests; (4) Partnership. Thus it is fair because people who do not own land are given the opportunity to participate in managing.

2. The principle of legal certainty, since the colonial era until now, forests have been constructed as state forests and private forests. Conflicts often occur between Perum Perhutani as state representative at the site level due to boundary issues. Through this program, people who have permission have legal certainty.
3. The principle of sustainability can be realized if the management of forest resources reaches balance between the demands of the people's needs and the benefits and preservation of forests and diversity.

4. Principle of participation. This principle involves the community as the manager and supervisor of forest data sources.

5. Principle of accountability. In the context of social forestry, this principle implies that the permit holder is obliged to implement everything stated in the Decree of the Minister of Environment and Forestry including its rights and prohibitions.

The above principles if it can be implemented well then the community increases the dignity of the poor, so they can escape the pitfalls of poverty and underdevelopment [5].

b. Ministerial Regulation of Village Number 16 Year 2019 concerning Determination of Village fund Priorities [6].

His commitment to the success of the village fund program which is the mainstay of President Joko Widodo's administration. This commitment is evidenced that the use of village funds is determined every year through [6]. Article 3 [6], stipulates that the priority of using village funds is based on the principles, among others:

1. Participatory: prioritizing the initiative, creativity, and participation of the rural community;

2. Self-management: prioritizing village independence in implementing village development activities funded by the Village fund.

3. Independent: prioritizes the use of Village funds by utilizing Village resources to finance development activities that are managed from, by and for the Rural community so that the Village fund rotates sustainably in the Village area and/or district/city area.

4. Village-based resources: prioritizing the utilization of human and natural resources in the village in the implementation of development funded by the Village fund.

While Priority of Village funds is set in Article 4 of Chapter III [6] Priority of Rural Development Fund are:

a. The use of Village funds is prioritized to finance the implementation of programs and activities in the field of Village development and empowerment of the Rural community.

b. The priority of using the Village fund as referred to in paragraph (1) can be used to finance the implementation of cross-cutting priority programs and activities.

c. The priority in the use of village funds as referred to in paragraph (1) and paragraph (2), is expected to provide maximum benefits to the rural community in the form of improving the quality of life, improving welfare and poverty reduction and increasing public services at the rural level.

\section{c. Law Number 6 of 2014 concerning Villages}

Law [1] mandates that villages are regulated by keeping in mind several principles including independence, participation, empowerment and sustainability (Article 3 [1]). There are still many villages that actually have a lot of 
potential but not yet developed. Whereas the implementation of Village Government is based on legal certainty, orderly administration of government, orderly public interest, openness, proportionality, professionalism, accountability, effectiveness and efficiency, local wisdom, and participation.

Considering the task of the village head is to carry out village governance, carry out village development, rural community development, and empowerment of the rural community, the task of the village head is so extensive. The Village Head has the authority to, among other things, hold the power to manage village finances and assets, establish village regulations, and determine the Village Budget (Article 26 [1]).

In line with the government's determination to make villages the subject of development, village arrangements are intended to encourage initiatives, movements and participation of village communities to develop village potentials and assets for mutual prosperity. Improve public services for villagers to accelerate public welfare (Article 4 [1]).

To improve rural livelihoods and sustainable management of forest resources, decentralized forest management is widely considered one of the most feasible options. Participatory Forest Management (PFM), a form of decentralization has been adopted by more than 21 African countries as an alternative method for managing forest resources. Furthermore [7] cite several sources that PFM is the involvement of local communities in forest management [8]. This is done through a process of inclusion, equity and democratization of forest resource governance [9].

\section{d. Village Empowerment through Social Forestry}

The empowerment itself is interpreted by Hermansyah as effort made in order to develop the ability and independence of individuals or communities in meeting their needs. The public can know the potential and problems faced and able to solve it [10]. Therefore, the models of sustainable forest management that have been outlined in various laws and regulations need to be welcomed by stakeholders.

LMDH of Green Belt of the Lembung Village Galis Sub District Pamekasan Regency as a reference area. The results of the field research found that mangrove forests in Lembung village had the potential to be polished into ecotourism while there was no involvement from village government, NGOs or content academics [2]. Therefore, it is necessary to have effort to empower the rural community concerned by keeping in mind the empowerment of the community in the area of the FMU with the other KPHs of course very different in touching it. For this reason, the identification of the potential of the area to be implemented will be very important in addition to the required infrastructure. Because it will determine what programs will be implemented there, what methods and materials are needed to match the cultural characteristics and desires of the local community.

Green tourism village development policies [11] which are principled include: (1) Involving and benefiting the community; (2) implementing conservation-based tourism development products; (3) base conservation-based local resources; (4) encourage the realization of the linkage between the tourism business and other supporting businesses. All of these are carried out on the basis of: (1) Appreciation for the local wisdom of the rural community;
(2) Authenticity and uniqueness influenced by local economic and socio-cultural conditions and development; (3) Can continue and creatively develop their rural identity or characteristics; (4) Mutually beneficial cooperation between business actors and minimizing the existence of negative competition between villages which can weaken the existing business climate.

If the community holds forest resource management permit through a social forestry program by getting support from village funds, the village will become more empowered. In such context, it is true as stated by Ngabiyanto that the concept of thematic village is more on offering the community to be proactively involved, so that it is not only community based but also the creation of sustainable and unique village spaces by the community [12].

\section{CONCLUSION}

Normatively, the opportunity for village empowerment through Social Forestry is very possible, but at the level of implementation it depends very much on how the responses of all stakeholders namely the village government, Forest Rural community Institutions, Social Forestry permit holders and local governments.

\section{REFERENCES}

[1] Law Number 6 of 2004 concerning Villages.

[2] Ministerial Regulation of Environment and Forestry Number: P.83/MENKLH/SETJEN/KUM.1/10/2016.

[3] Nicholas K. Menzies, "Partners in Governing the Forests: Reviewing Community-Based Forest Management," 2019.

[4] Wartiningsih, "Reconstruction of the Model of Social Forestry Policy in Madura," 2019.

[5] Badarrudin, "Community empowerment Based on Social Capital and Village Business Company (BUMDes)," in Advances in Social Science, Education and Humanities Research, International Conference on Social and Political Development (ICOSOP) Atlantis Press, 2017.

[6] Ministerial Regulation of Villages, Development of Disadvantaged Regions, and Transmigration of the Republic of Indonesia. Indonesia, 2019.

[7] J. M. M. R. G. W. D. N. Mungai, "Local Participation in Community Forest Associations: A Case Study of Sururu and Eburu Forests, Kenya," Int. J. African Asian Stud.

[8] Arun Agrawal and Jesse Ribot, "Accountability in Decentralization: A Framework with South Asian and West African Cases."

[9] A. A. and K. Gupta, "Decentralization and Participation: The Governance of Common Pool Resources in Nepal's Terai," 2005.

[10] E. Hartatik, "Mosque-Based Economic Empowerment as a Model for Poverty Alleviation (Case Study of Baiturrahman Cooperative Lkidon Sukoharjo Ngaglik Sleman Yogyakarta),” 2017.

[11] Republic Indonesia Ministry of Cooperatives and SMEs, Green Tourism Village Development Guidebook. 2015. 
[12] Ngabiyanto, "Empowering and Developing The Local Potency Through Thematic Village in Semarang"," in Advances in Social Science, Education and Humanities Research (ASSEHR) International Conference on Rural Studies in Asia (ICoRSIA 2018), 2018. 